J. Perinat. Med. 3 (1975) 53

\title{
Recognition and significance of maternogenic fetal acidosis during intensive monitoring of labor
}

\author{
G. D. Roversi, V. Canussio, M. Spennacchio \\ Institute of Obstetrics and Gynecology "L. Mangiagalli" \\ University of Milan, 1st. Department \\ (Director: Prof. Dr. G. B. Candiani)
}

Received November 28, 1973. Accepted April 4, 1974.

The rapid propagation of techniques for intensive monitoring of the fetus-at-risk during labor, i. e. fetal heart rate (FHR) monitoring and fetal blood sampling (FBS), has resulted in the accumulation of considerable clinical experience in this area within a short period of time.

The problem of choosing between these two methods for routine use now seems to have been solved; it has become clear that the two are mutually complementary $[3,9,14,15,31,34,42]$. In general, the purpose of FBS and fetal $\mathrm{pH}$ determination is to reduce the margin of error inherent in assessing the fetal condition by means of the cardiotachometer tracing. The clinical and acid-base status of the infant at birth may in fact be good, not only when the FHR has remainded normal during labor (regular, or with early deceleration), but also in a high percentage of cases showing abnormal or even highly abnormal deceleration (late deceleration) $[3,12,22,27,31$, 34, 42].

Monitoring of FHR allows for continuous assessment of the fetal status during labor, whereas microanalysis of $\mathrm{pH}$ from FBS is at present still intermittent. In practical terms this means that both methods may be employed to advantage: FHR monitoring should be used for preliminary screening of all cases at risk, and microanalysis of the fetal blood as a guide to the obstetric management of labor once pathological changes in the FHR have been detected. If clinical management is to be based on the actual condition of the fetus, it becomes imperative to obtain an exact picture of the fetal acid-base balance in appropriate cases. The main problem in this regard is one of false positives or falsely abnormal results, i. e., the cases (by no means rare) in which a low fetal $\mathrm{pH}$ during labor does not reflect a state of fetal hypoxia $[2,6$, $20,27,31]$. The good clinical condition of these infants at birth (APGAR $\geqq 7$ ) indicates that rapid extraction of the fetus is not justified in such cases. A number of methods have been proposed for the recognition of this type of acidosis during labor, but certain questions regarding the validity of these methods and their ability to meet the particular clinical requirements of the delivery room $[2,19,26,28,31]$ are still unanswered. The data presented below were compiled at the First Clinic of Obstetrics and Gynecology of the Milan University during the period 1968-1972.

\section{Cases and methods}

59 normal cases (normal pregnancy, normal onset of labor at term, clear amniotic fluid, regular FHR, spontaneous delivery, APGAR 8-10 at 90 seconds, weight at birth $>2,500 \mathrm{~g}$ ), and 335 cases regarded as being at risk (maternal disease, presence of meconium stained amniotic fluid and/or abnormalities in FHR) were followed during labor by monitoring of FHR and microanalysis of fetal blood.

\subsection{Monitoring of the FHR and uterine contractions}

Biophysical monitoring was carried out by means of a Hewlett-PACKARD 8020A cardiotokograph. 
The FHR was taken from the fetal ECG recorded with a silver suction electrode applied to the scalp [40], and more recently with a HoN clip [16] or spiral [17] electrode. Uterine contractions were recorded with an abdominal lead, or when possible, with a transvaginal intra-amniotic catheter. The tracings were interpreted according to HoN [16].

\subsection{Determination of acid-base balance}

Microsamples of fetal blood were obtained by the method of SaLING [30]. Simultaneous samples of the mother's blood were taken from the tip of the finger after arterialisation with ethyl chloride and smearing with vaseline. Both samples were subjected to identical chemical analysis, and all measurements were carried out in duplicate.

pH and pH qu 40 were measured with a SALING-TuRowski $\mathrm{pH}$ meter [30].

Hemoglobin concentration was determined with a BECKMAN spectrophotometer, after the addition of DRABKIN's solution.

'Hemoglobin- $\mathrm{O}_{2}$-saturation (\%) was measured photometrically using an OSM 1 RADIOMETER Oxygen Saturation Meter [1, 39].

Base deficit (BD) and Base deficit $\mathrm{Hb}_{5}\left(\mathrm{BD}_{\mathrm{H} \mathrm{H}_{5}}\right)$ were calculated from the SIGGAard-ANDERSEN nomogram [35] using the $\mathrm{pH}$ qu 40 value and the hemoglobin concentration; $\mathrm{BD}$ values were corrected for hemoglobin- $\mathrm{O}_{2}$-saturation. The $\mathrm{PCO}_{2}$ value was indirectly derived, and the $\mathrm{BD}_{\mathrm{H} b_{5}}$ calculated at the predetermined $\mathrm{Hb}$ level of $5 \mathrm{~g} / 100 \mathrm{ml}$ [37]. Materno-fetal (M/F) $\mathbf{\Delta B D _ { \mathrm { Hb } _ { 5 } }}$ (the difference between the fetal and maternal base deficits at a fixed $\mathrm{Hb}$ level of $5 \mathrm{~g} /$ $100 \mathrm{ml}$ ) was calculated by subtracting the corrected fetal from the maternal base deficit [19].

$\mathrm{M} / \mathrm{F}$ actual $\Delta \mathrm{pH}, \mathrm{M} / \mathrm{F} \Delta \mathrm{pHqu} \mathbf{4 0}$ are the materno-fetal differences in actual $\mathrm{pH}(26)$ and in pHqu 40 [31] respectively. Samples of maternal blood and of arterial and venous cord blood were taken immediately after delivery and subjected to identical microanalyses. The clinical condition of the infant 90 seconds after birth was evaluated by the APGar score.

\section{2 'Falsely abnormal' cases and maternogenic fetal acidosis}

Fetal $\mathrm{pH}$ values obtained shortly before delivery normally compare well with those of blood from the umbilical artery, and with the clinical condition of the infant at birth [6]. In some cases, however, the fetal $\mathrm{pH}$ during labor does not agree with the clinical condition at birth. A low $\mathrm{pH}(<7.20)$ in these instances leads one to expect the delivery of a distressed infant, whereas the APGAR score proves to be $\geqq 7[2,6,20,27,31]$.

The overall incidence of such "falsely abnormal" cases - false because the infant is in good condi-
Tab. I. Incidence of 'falsely abnormal' cases (fetal $\mathrm{pH}<7.20$ within 30 minutes of delivery; Apgar score $1-2$ minutes after birth $\geqq 7$ ) in 4 series.

\begin{tabular}{lcc}
\hline \multicolumn{1}{c}{ Author } & No. of cases & $\begin{array}{c}\text { 'Falsely abnormal' } \\
(\%)\end{array}$ \\
\hline BEARD R. W. et al. & 176 & 13.1 \\
[5] & 77 & 12.9 \\
KUBLI F. & 355 & 7.6 \\
[21] & 179 & 11.2 \\
BowE E. T. et al. & Present series* & \\
\hline
\end{tabular}

* Cases at risk

tion at birth, and abnormal because the fetal acidbase state during labor was found to be abnormal [20] - is nearly identical in all reported series $[5,6,21]$; in our own series they comprised $11.2 \%$ [29] of the cases at risk (Tab. I). In the absence of measures to detect these cases, rapid extraction of the fetus will be erroneously indicated in at least one out of every 10 cases at risk.

As a first step in solving this problem it is necessary to determine the cause of this type of fetal acidosis without associated hypoxia.

Investigations both in human subjects and in animals have shown that artificially induced acidosis or alkalosis in the mother causes a shift of the fetal acid-base balance in the same direction $[8,10,13,24]$. The detailed mechanism of this dependence and the part played by the placenta are far from clear, but in normal labor an increase in the content of fixed acid radicals in the mother (mainly due to the uterine "contractions) is accompanied by a similar increase in the fetus $[11,19]$. This does not normally lead to any significant decrease in fetal $\mathrm{pH}$, but the latter may be considerably decreased in cases where uterine contractions are particularly strong (spontaneous or iatrogenic hyperkinesia) and/or the clinical condition of the mother is such as to produce severe metabolic acidosis (prolonged labor, toxemia, diabetes, inadequate nutrition and care during labor, drugs, etc.). This secondary fetal acidosis does not appear to be harmful to the fetus, and according to some reports $[7,23]$ it could actually favour oxygenation.

The following parameters have been proposed to distinguish fetal hypoxic acidosis from 
maternogenic acidosis and to ensure that the measurement of fetal $\mathrm{pH}$ during labor maintains its diagnostic and prognostic value: $\mathrm{F} / \mathrm{M} \triangle \mathrm{BD}$ [2], $\mathrm{M} / \mathrm{F} \Delta \mathrm{pH}$ qu 40 [31], $\mathrm{M} / \mathrm{F}$ actual $\Delta \mathrm{pH}[26]$, and $\mathrm{M} / \mathrm{F} \Delta \mathrm{BD}_{\mathrm{H}_{5}}[19,28]$.

\section{Methods for the diagnosis of maternogenic fetal acidosis}

\subsection{Difference between fetal and maternal $\mathrm{BD}(\mathrm{F} / \mathbf{M} \Delta \mathrm{BD})$}

On the basis of the pathophysiologic observations outlined above it appears that hypoxic fetal acidosis may be distinguished from acidosis of maternal origin by comparison of the metabolic component of the acid-base balance in the mother and in the fetus. In maternogenic fetal acidosis the relationship between the two should be normal, since the fetal acidosis is merely a reflection in the fetus of the metabolic acidosis in the mother. In fetal hypoxic acidosis on the other hand, there should be a change in the relationship owing to the accumulation of lactic acid in the fetus as a result of anaerobic metabolism $[2,19]$. BEARD et al. [2] have shown that when the BD (not corrected for the $\mathrm{O}_{2}$ saturation of the hemoglobin) is used as a parameter for the measurement of the metabolic component of the acid-base balance, the fetal values are normally slightly higher than the maternal values $(\mathrm{F} / \mathrm{M} \triangle \mathrm{BD}=2.0$ $-3.0 \mathrm{mEq} / \mathrm{l}$ ). This value has therefore been proposed as the boundary between the two forms of acidosis, and would be exceeded only in fetal hypoxic acidosis.

Difficulties may arise in the use of the $\mathrm{BD}$ for the differential diagnosis of fetal acidosis unless it is corrected for the $\mathrm{O}_{2}$ saturation of the hemoglobin, for the following reasons:

(a) The uncorrected fetal $\mathrm{BD}$ is higher than the true value

The BD is read directly from the SIGGAARD-ANDERSEN nomogram [35], after construction of the buffer line by equilibration of the blood sample with gas mixtures containing $\mathrm{O}_{2}$. During the equilibration the fetal $\mathrm{Hb}$ in the reduced state becomes oxygenated, and the greater acidity of oxygenated $\mathrm{Hb}$ in comparison with reduced $\mathrm{Hb}$ causes an increase in the in vitro $\mathrm{BD}$ in comparison with the in vivo value*. This error is invariably of considerable degree, owing to the

* According to SrggaARd-ANDERsen's definition of base deficit, the BD would be calculated at the actual hemoglobin oxygen saturation [38].

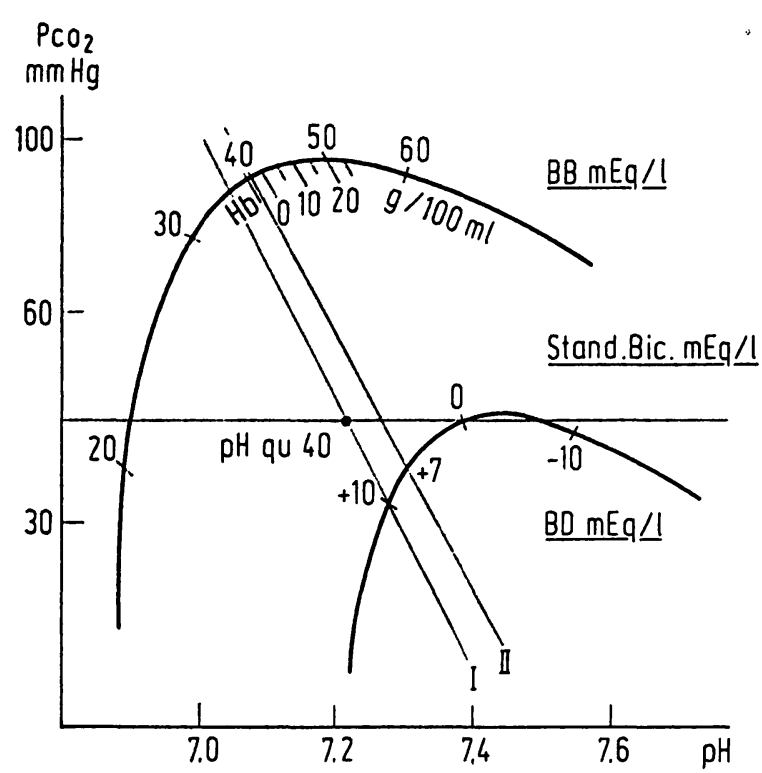

Fig. 1. Calculation of $\mathrm{BD}$ according to fetal $\mathrm{Hb}$ oxygen saturation: Actual pH 7.20, pHqu $407.24, \mathrm{Hb} 15 \mathrm{~g} / 100 \mathrm{ml}$, $\mathrm{O}_{2}$ saturation $33.3 \%$

First line - uncorrected BD (10 mEq/l)

Second line - corrected BD $(7 \mathrm{mEq} / \mathrm{l})$

high percentage of reduced $\mathrm{Hb}$ present in fetal blood. Particular variation may exist from case to case, since it depends (see the formula of SIgGAARD-ANDERSEN and ENGEL [38]) on two extremely variable factors, i. e. the amount of $\mathrm{Hb}$ present and its percentage oxygen saturation. Even with normal fetal values for $\mathrm{Hb}(15-20 \mathrm{~g} / 100 \mathrm{ml})$ and for the oxygen saturation ( $20-50 \%$ ), the error caused by ignoring correction for oxygenation amounts to an increase in $\mathrm{BD}$ varying between $2.2-4.8 \mathrm{mEq} / \mathrm{l}$ (Fig. 1). (b) The fetal BD is higher than the maternal value In view of the false increase in fetal $\mathrm{BD}$, the materno-fetal $\mathrm{BD}$ difference $(\mathrm{M} / \mathrm{F} \triangle \mathrm{BD})$ is negative in normal labor, i. e. the fetal $B D$ is higher than the maternal.

Analysis of the metabolic components of maternal and fetal acid-base balance shows [19] that the maternal $\mathrm{BD}$ is actually higher than the fetal value in vivo (see below).

\subsection{Differences between maternal and fetal pHqu 40 (M/F $\Delta$ pHqu 40)}

The $\mathrm{pHqu} 40$ [30] is the $\mathrm{pH}$ of the blood after equilibration with $\mathrm{CO}_{2}$ \at a partial pressure of $40 \mathrm{~mm} \mathrm{Hg}$, and corresponds to the standard bicarbonate. It has the advantage of expressing the metabolic component of the acid-base balance in terms of $\mathrm{pH}$.

SALING [31] has proposed the simultaneous determination of maternal and fetal $\mathrm{pHqu} 40$ for the diagnosis of fetal acidosis of maternal origin. By his definition a fetal acidosis of maternal origin would be restricted to a difference of not greater 
than $0.05 \mathrm{pH}$ units between the maternal and the fetal values (M/F $\Delta \mathrm{pHqu} 40)$, this limiting value having been established empirically [31].

The pHqu 40 is a parameter that can be determined quickly and easily, but the technique requires complete oxygenation of the blood sample. In the SIGGAARD-ANDERSEN nomogram, the buffer line giving the $\mathrm{BD}$ for fully oxygenated blood passes through the pHqu 40 value (Fig. 1). The use of the pHqu 40 is therefore open to the same criticism as is $\mathrm{BD}$ (see foregoing paragraph).

\subsection{Differences between the actual maternal and fetal $\mathrm{pH}(\mathrm{M} / \mathrm{F}$ actual $\Delta \mathrm{pH})$}

The mean fetal $\mathrm{pH}$ determined during normal labor may vary considerably from one maternity unit to another [26]. In view of the close relation'ship between the maternal and the fetal acid-base balance this is probably due to variations in maternal metabolic acidosis during labor in different Units.

To overcome this difficulty, and to enable all maternity units to express the fetal acid-base condition in units that are truly comparable, it has been suggested that actual fetal $\mathrm{pH}$ should be replaced by difference in maternal and fetal actual $\mathrm{pH}(\mathrm{M} / \mathrm{F}$ actual $\Delta \mathrm{pH})[26]$. Fetal pH-normality, pre-acidosis, and frank acidosis would thus be redefined and characterized respectively. by an $\mathrm{M} / \mathrm{F}$ actual $\Delta \mathrm{pH}$ of $<0.15, \mathrm{M} / \mathrm{F}$ actual $\Delta \mathrm{pH}$ of between $0.15-0.19$, and $\mathrm{M} / \mathrm{F}$ actual $\Delta \mathrm{pH} \geqq 0.20$. This classification is based on the close correlation found between $\mathrm{M} / \mathrm{F}$ actual $\Delta \mathrm{pH}$ and fetal $\mathrm{P}_{\mathrm{O} 2}$ [26]. The use of $\mathrm{M} / \mathrm{F}$ actual $\Delta \mathrm{pH}$ instead of the actual $\mathrm{pH}$ in the evaluation of the fetal condition during labor would clearly also overcome the problem of differential diagnosis between fetal acidosis due to hypoxia and that of maternal origin.

A preliminary analysis suffices to show that it would be unwise to use the difference in $\mathrm{pH}$ between mother and fetus for the diagnosis of fetal hypoxia, or to thusly estimate its degree of severity. The same concentration of hydrogen ions may be expressed by very different $\Delta \mathrm{pH}$ values, and vice versa, since $\mathrm{pH}$ is logarithmic. In Tab. II, for example, the same hydrogen ion concentration (23.2-23.3 nmol/1) corresponds both to an $\mathrm{M} / \mathrm{F}$ actual $\Delta \mathrm{pH}$ of 0.20 (actual $\mathrm{pH}: \mathrm{M} 7.40 ; \mathrm{F} 7.20$ ),
Tab. II. Disagreement between $\Delta \mathrm{pH}$ and $\Delta\left[\mathrm{H}^{+}\right]$. Continuous lines enclose different $\Delta \mathrm{pH}$ values for identical $\Delta\left[\mathrm{H}^{+}\right]$; broken lines enclose identical $\Delta \mathrm{pH}$ values for different $\Delta\left[\mathrm{H}^{+}\right]$values.

\begin{tabular}{cccc}
\hline $\mathrm{pH} \mathrm{M}$ & $\mathrm{pH} \mathrm{F}$ & $\Delta \mathrm{pH}(\mathrm{M} / \mathrm{F})$ & $\Delta\left[\mathrm{H}^{+}\right] \mathrm{nmol} / \mathrm{l}$ \\
\hline 7.40 & 7.30 & 0.10 & 10.3 \\
7.30 & 7.20 & 0.10 & 13.0 \\
7.20 & 7.10 & 0.10 & 16.3 \\
7.40 & 7.25 & $0.15 \vdots$ & $16.4 \vdots$ \\
7.30 & 7.15 & $0.15 \vdots$ & $\vdots 20.7 \vdots$ \\
7.25 & 7.10 & $\vdots 0.15 \vdots$ & $23.2 \vdots$ \\
7.40 & 7.20 & 0.20 & 23.3 \\
7.30 & 7.10 & 0.20 & 29.3 \\
\hline
\end{tabular}

Tab. III. Correlations: $\mathrm{M} / \mathrm{F}$ actual $\Delta \mathrm{pH} /$ fetal $\mathrm{P}_{2}$ and $\mathrm{M} / \mathrm{F}$ actual $\Delta \mathrm{pH} /$ fetal $\mathrm{Hb}=\mathrm{O}_{2}$ saturation.

\begin{tabular}{|c|c|c|c|c|c|}
\hline \multirow[t]{2}{*}{ Author } & \multirow[t]{2}{*}{$\begin{array}{l}\text { No. of } \\
\text { cases }\end{array}$} & \multicolumn{2}{|c|}{$\underset{\mathrm{M} / \mathrm{F} \text { actual } \Delta \mathrm{pH} /}{\mathrm{P}_{\mathrm{O}_{2}} \mathrm{~F}}$} & \multicolumn{2}{|c|}{$\begin{array}{l}\mathrm{M} / \mathrm{F} \text { actual } \Delta \mathrm{pH} / \\
\quad \text { sat. } \mathrm{O}_{2} \mathrm{~F}\end{array}$} \\
\hline & & $\mathbf{r}$ & $\mathrm{p}$ & $\mathbf{r}$ & $\mathrm{p}$ \\
\hline & 31 & $\sim 0.68$ & ○ 001 & 0.72 & \\
\hline Present ser & 327 & 0.02 & & 0.28 & $<0.001$ \\
\hline
\end{tabular}

$\sim=$ calculated from graphically reported data [26].

and to an $\mathrm{M} / \mathrm{F}$ actual $\Delta \mathrm{pH}$ of 0.15 (actual $\mathrm{pH}$ : M 7.25; F 7.10).

Moreover, a retrospective study of our own series had failed to confirm any close correlation between $\mathrm{M} / \mathrm{F}$ actual $\Delta \mathrm{pH}$ and fetal scalp blood $\mathrm{P}_{\mathrm{O} 2}$ (Tab. III).

For all these reasons it is our opinion that the clinical use of this parameter does not provide an accurate evaluation of the fetal acid-base balance during labor, and does not solve the problem of recognizing 'falsely abnormal' cases.

\subsection{Materno-fetal difference in base deficit of the extracellular fluid $\left(M / F \Delta B D_{\mathrm{H}_{5}}\right)$ \\ 3.4.1 Base deficit of the extracellular fluid $\left(\mathrm{BD}_{\mathrm{H} b_{5}}\right)^{*}$}

As indicated above, any accurate comparison of the metabolic component of the maternal and fetal acid-base balance with the $\mathrm{BD}$ as the parameter necessitates correction of the $\mathrm{BD}$ for $\mathrm{O}_{2}$

\footnotetext{
* In this paper the term $\mathrm{BD}_{\mathrm{Hb}}$ is used in order to reflect the way the data are obtained. However, the modern terminology prefers to use the term $\mathrm{BD}_{\mathrm{ECF}}$ (base deficit of the extracellular fluid).
} 
hemoglobin saturation (Fig. 1). This correction may be performed by means of the formula of SiggaArd-ANDERSEN and ENGel [38].

However, another correction is necessary to eliminate the false increase in the $\mathrm{BD}$ that occurs in vivo with hypercapnia, which is almost a normal occurrence in the fetus during labor. In cases involving hypercapnia the increased $\mathrm{CO}_{2}$ comes out of the intracellular compartment and enters the red cells, where bicarbonate is generated. This bicarbonate from the red cells diffuses out of the blood into the interstitial fluid. The intravascular

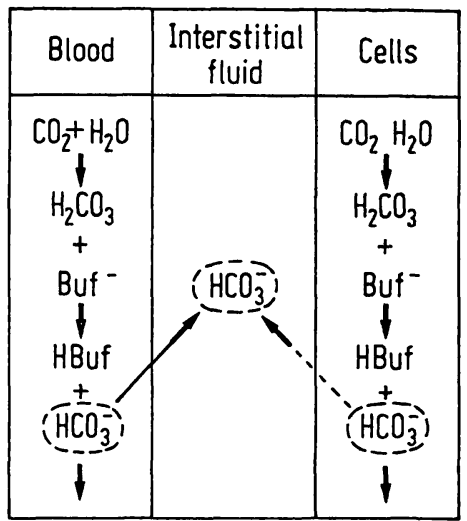

Fig. 2. Model showing bicarbonate redistribution in vivo in a case of hypercapnia. Buf ${ }^{-}=$all buffers other than bicarbonate. For every Buf- consumed, one bicarbonate ion is produced, some of which "leaks" into the interstitial fluid. Base deficit therefore increases [41].

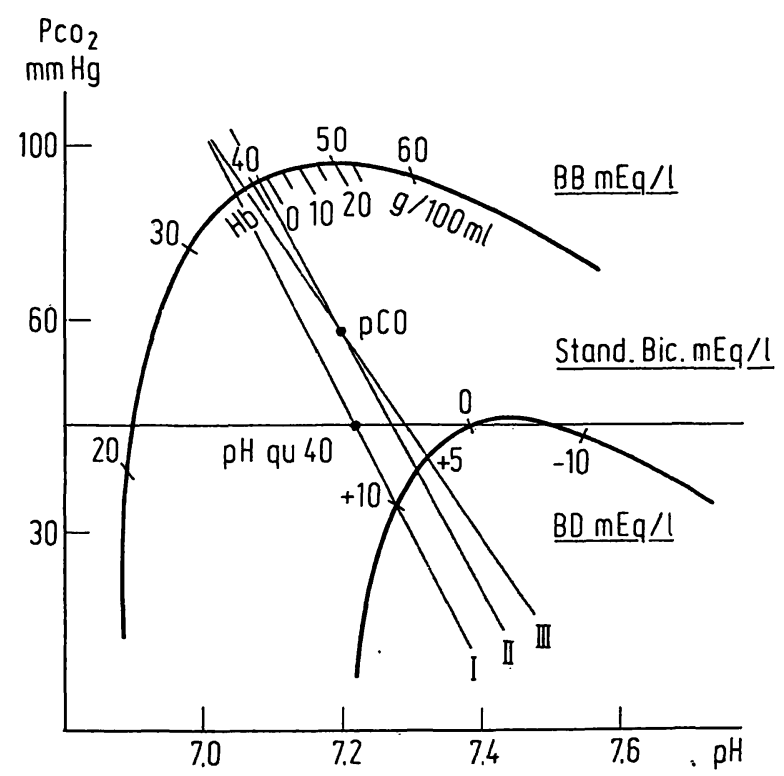

Fig. 3. Calculation of fetal $\mathrm{BD}$ at the prefixed $\mathrm{Hb}$ value of $5 \mathrm{~g} / 100 \mathrm{ml}, \mathrm{O}_{2}$ saturation $33.3 \%$

First line - uncorrected BD $(10 \mathrm{mEq} / \mathrm{l})$

Second line - corrected BD $(7 \mathrm{mEq} / \mathrm{l})$

Third line - BD for $\mathrm{Hb} 5 \mathrm{~g} / 100 \mathrm{ml}(5 \mathrm{mEq} / \mathrm{l})$ space therefore looses bicarbonate and blood $\mathrm{BD}$ increases, even though there is no real increase in the degree of metabolic acidosis present (Fig. 2) [41].

To prevent variations in $\mathrm{P}_{\mathrm{CO} 2}$ from being reflected in the $B D, i$. e. to ensure that the $B D$ value includes bicarbonate that has diffused from the blood into the interstitial fluid, SIGGAARDANDERSEN proposes using the $\mathrm{BD}$ of the extracellular fluid [37]. This is calculated on the basis of the amount of red cells distributed throughout the interstitial space, at a $\mathrm{Hb}$ concentration of $5 \mathrm{~g} / 100 \mathrm{ml}\left(\mathrm{BD}_{\mathrm{H}_{5}}\right)$ (Fig. 3).

It has been shown experimentally that in both maternal and fetal blood the $\mathbf{B D}_{\mathrm{H} b_{5}}$ is independent of the $\mathbf{P}_{\mathrm{CO}_{2}}$, and that the values obtained from the SIgGAARD-ANDRSEN nomogram are identical with those calculated on the basis of $\mathrm{pH}$, $\mathrm{P}_{\mathrm{CO} 2}$, plasma protein, and $\mathrm{Hb}$ concentration [25].

\subsection{2 $\mathrm{M} / \mathrm{F} \Delta \mathrm{BD}_{\mathrm{H} \mathrm{b}_{5}}$ in normal labor}

Workers in Sweden were the first to use the $\mathrm{BD}_{\mathrm{H}_{\mathrm{b}_{5}}}$ for the evaluation of the acid-base balance during labor and the $\mathrm{M} / \mathrm{F} \triangle \mathrm{BD}_{\mathrm{H} \mathrm{b}_{5}}$ for the detection of 'falsely abnormal' cases $[19,25]$. JACOBSON has shown that in normal labor [19] the fetal $\mathrm{BD}_{\mathrm{H}_{5}}$ remains lower than the maternal value, particularly during expulsion.

Probability analyses on the results of this study [28] show that the mean $\mathrm{M} / \mathrm{F} \triangle \mathrm{BD}_{\mathrm{H} \mathrm{b}_{5}}$ during labor is $+2.5 \mathrm{mEq} / 1 \pm 2.6$ (SD). This was confirmed in our own series of normal cases, the criteria adopted being the same as those used by the Swedish workers. Our mean was $+4.0 \mathrm{mEq} / 1$ $\pm 2.8(\mathrm{SD})$.

\subsubsection{Detection of 'falsely abnormal' cases Fy means of the $M / F \Delta B D_{H b_{5}}$}

It appeared desirable to Eonfirm that this method could be used for the detection of maternogenic fetal acidosis in "falsely abnormal" cases. For this purpose it was assumed that a positive $\mathrm{M} / \mathrm{F}$ $\triangle \mathrm{BD}_{\mathrm{H}} \mathrm{b}_{5}$ in the persence of a low $\mathrm{pH}$ still represents normal placental function, and hence indicates that the acidosis is of maternal origin, since a value of zero for $M / F \Delta B D_{H_{b}}$ equals $11 / 2 \mathrm{SD}(4.0-4.2 \mathrm{mEq} / \mathrm{l})$ downwards from normal cases. 
Tab. IV. Incidence of maternogenic fetal acidosis in "falsely abnormal" cases (actual $\mathrm{pH}<7.25$ during final 30 minutes of labor, APGAR $\geqq 7$ at 90 seconds after delivery).

\begin{tabular}{ccc}
\hline Actual fetal $\mathrm{pH}$ & $\begin{array}{c}\mathrm{M} / \mathrm{F} \Delta \mathrm{pHqu} 40 \\
\leqq 0.05\end{array}$ & $\mathrm{M} / \mathrm{F} \Delta \mathrm{BD}_{\mathrm{H}_{5}}>0$ \\
\hline$<7.25$ & $35.9 \%$ & $79.4 \%$ \\
$\begin{array}{c}(39 \text { cases }) \\
7.25-7.20\end{array}$ & $52.6 \%$ & $84.2 \%$ \\
$(19$ cases $)$ & $20.0 \%$ & $75.0 \%$ \\
$<7.20$ & & \\
\hline$(20$ cases $)$ & & \\
\hline
\end{tabular}

In a series of 179 cases at risk, the $M / F \Delta B D_{H_{b}}$ was positive in $79.4 \%$ of 'falsely abnormal' cases (actual pH $<7.25$, APGAR $\geqq 7$ ).

When the series was further delineated according to the degree of acidosis, the $\mathrm{M} / \mathrm{F} \Delta \mathrm{BD}_{\mathrm{Hb}}$ remained positive in $84 \%$ of the cases of preacidosis (actual pH 7.25-7.20) and in 75\% of the cases of frank acidosis (actual $\mathrm{pH}<7.20$ ) (Tab. IV).

The decrease in fetal $\mathrm{pH}$ in most of the "falsely abnormal" cases in our series was therefore due to increased metabolic acidosis in the mother. If the $\mathrm{M} / \mathrm{F} \Delta \mathrm{pHqu} 40$ had been used, on the other hand, the maternal origin of the fetal acidosis would have been recognised in considerably fewer cases; it was in fact less than 0.05 units in $35.9 \%$ of fetuses with an actual $\mathrm{pH}<7.25$, in $52.6 \%$ of those with actual $\mathrm{pH}$ values between 7.25 and 7.20 , and in $20 \%$ of those with an actual $\mathrm{pH}<7.20$ (Tab. IV). The difference in the ability of the two criteria to identify maternal origin of fetal acidosis is not without clinical importance, since a decision

Tab. V. Incidence of maternogenic fetal metabolic acidosis during labor and after delivery.

\begin{tabular}{|c|c|c|c|c|c|}
\hline Author & $\begin{array}{l}\text { No. of } \\
\text { cases }\end{array}$ & Parameter & $\begin{array}{l}\text { First } \\
\text { stage }\end{array}$ & $\begin{array}{l}\text { 2nd } \\
\text { stage }\end{array}$ & $\begin{array}{l}\text { Deli- } \\
\text { very }\end{array}$ \\
\hline & & Fetal pHqu 40 & $<7,25$ & & \\
\hline $\begin{array}{l}\text { SALING E } \\
{[31]}\end{array}$ & E. 118 & $\overline{\mathrm{M} / \mathrm{F} \Delta \mathrm{pHqu} 40}$ & $18.0 \%$ & $26.0 \%$ & $31.0 \%$ \\
\hline \multirow[t]{2}{*}{$\begin{array}{l}\text { Present } \\
\text { series }\end{array}$} & 101 & $\begin{array}{l}\mathrm{M} / \mathrm{F} \Delta \mathrm{pHqu} 40 \\
\mathrm{M} / \mathrm{F} \Delta \mathrm{BD}_{\mathrm{H}} \mathrm{b}_{5}\end{array}$ & $\begin{array}{r}8.5 \% \\
64.4 \%\end{array}$ & $\begin{array}{l}28.0 \% \\
66.7 \%\end{array}$ & $\begin{array}{l}55.0 \% \\
90.1 \%\end{array}$ \\
\hline & & Fetal actual $\mathrm{pH}$ & $<7,25$ & & \\
\hline $\begin{array}{l}\text { Present } \\
\text { series }\end{array}$ & 139 & $\begin{array}{l}\bar{M} / \mathrm{F} \Delta \mathrm{pHqu}_{40} \\
\mathrm{M} / \mathrm{F} \Delta \mathrm{BD}_{\mathrm{Hb}}\end{array}$ & $\begin{array}{l}31.9 \% \\
75.3 \%\end{array}$ & $\begin{array}{l}15.8 \% \\
68.4 \%\end{array}$ & $\begin{array}{l}59.7 \% \\
88.5 \%\end{array}$ \\
\hline
\end{tabular}

as to the future management of labor depends on the diagnosis.

It has recently been reported $[31,33]$ that when the $\mathrm{M} / \mathrm{F} \Delta \mathrm{pHqu} 40$ is used as the indicator, the incidence of maternogenic fetal metabolic acidosis is $18 \%$ and $26 \%$ during the first and second stages of labor respectively. In our own series the same parameter gave $8.5 \%$ in the first stage and $28 \%$ in the second, whereas the $\mathrm{M} / \mathrm{F} \Delta \mathrm{BD}_{\mathrm{H} \mathrm{b}_{5}}$ gave a much higher incidence $(64.4 \%$ and $66.7 \%$ respectively). The incidence is even higher in cases with actual $\mathrm{pH}<7.25$ (Tab. V).

\subsubsection{Correlation between $\mathrm{M} / \mathrm{F} \Delta \mathrm{BD}_{\mathrm{H} \mathrm{b}_{5}}$ and $\triangle \mathrm{pHqu} 40$}

The different results obtained when the $M / F$ $\Delta \mathrm{pHqu} 40$ and the $\mathrm{M} / \mathrm{F} \Delta \mathrm{BD}_{\mathrm{H}_{5}}$ are used for the identification of "falsely abnormal" cases are at variance with the good statistical correlation found between the two parameters. The coefficient of correlation in a recent series was high $(r=0.98)$ [33], and good correlation was also found $(\mathrm{r}=0.80)$ [28] in our own series (578 microsamples from 303 cases of labor) (Fig. 4).

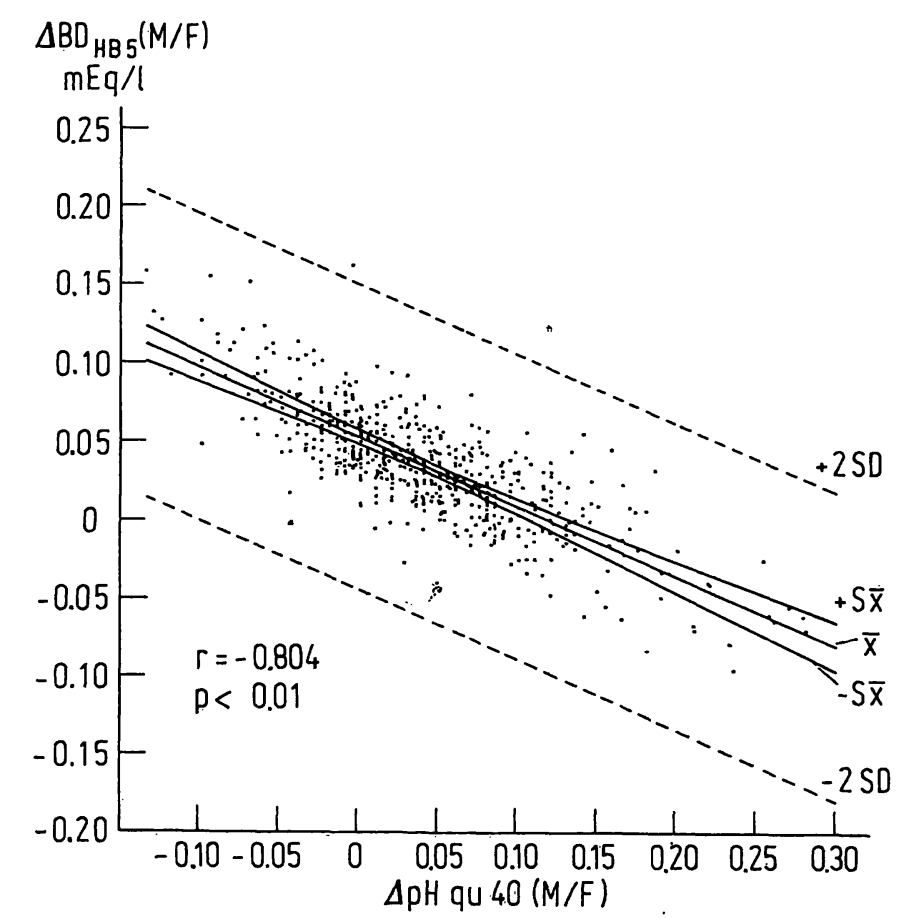

Fig. 4. Correlation between $\mathrm{M} / \mathrm{F} \Delta \mathrm{pHqu} 40$ and $\triangle \mathrm{BD}_{\mathrm{H} \mathrm{b}_{5}}$ during labor for cases at risk

No. of cases : 303

No. of blood microsamples: 578 


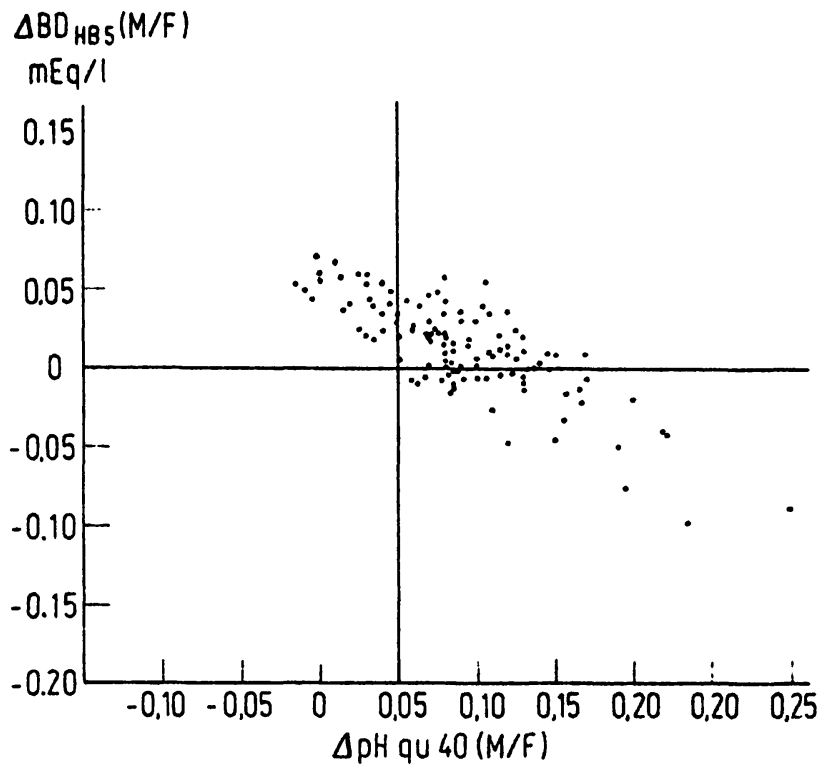

Fig. 5. Correlation between $\mathrm{M} / \mathrm{F} \Delta \mathrm{pHqu} 40$ and $\Delta \mathrm{BD}_{\mathrm{H}_{5}}$ in fetal acidosis (actual fetal pH $<7.25$ ), and its clinical implications (sec text)

No. of cases: 87

No. of samples: 117

If a system of axes with the ordinate at $0.05 \mathrm{pH}$ units and the abscissa at a $\triangle B D_{\mathrm{H}_{5}}$ value of 0 (limiting values of the two parameters for distinguishing hypoxic and maternogenic fetal acidoses) are inserted in the context of the correlation between $\triangle \mathrm{BD}_{\mathrm{H}_{\mathrm{b}}}$ and $\Delta \mathrm{pHqu} 40$ (fetuses with actual $\mathrm{pH}<7.25$ ), two points of interest emerge. Firstly, in our own experience there are no negative values for $\mathrm{M} / \mathrm{F} \triangle \mathrm{BD}_{\mathrm{H} \mathrm{b}_{5}}$ when the $\mathrm{M} / \mathrm{F}$ $\triangle \mathrm{pHqu} 40$ is less than 0.05 . Secondly, the $\triangle \mathrm{BD}_{\mathrm{H} \mathrm{b}_{5}}$ may have a positive value even when the $\Delta \mathrm{pHqu} 40$ is greater than 0.05 (Fig. 5).

In clinical terms this means that in fetal acidosis, a $\mathrm{M} / \mathrm{F} \Delta \mathrm{pHqu} 40 \leqq 0.05$ pretty well rules out fetal hypoxia as the cause [28,33], whereas a value greater than 0.05 does not necessarily rule out a maternal etiology [28].

\subsubsection{Prognostic value of $\mathrm{M} / \mathrm{F} \Delta \mathrm{BD}_{\mathrm{H} \mathrm{b}_{5}}$ in the presence of variable FHR during labor}

The diagnostic and prognostic value of the $\mathrm{M} / \mathrm{F} \triangle \mathrm{BD}_{\mathrm{H}_{b_{5}}}$ during labor was pointed out in 1970 [27]. In cases where the FHR varied during the 90 minutes preceding delivery, the $M / F$ $\triangle \mathrm{BD}_{\mathrm{Hb}_{5}}$ proved to be negative in every case where the subsequent APGAR score was $\leqq 4$, and positive when it was $\geqq 8$. Intermediate clinical

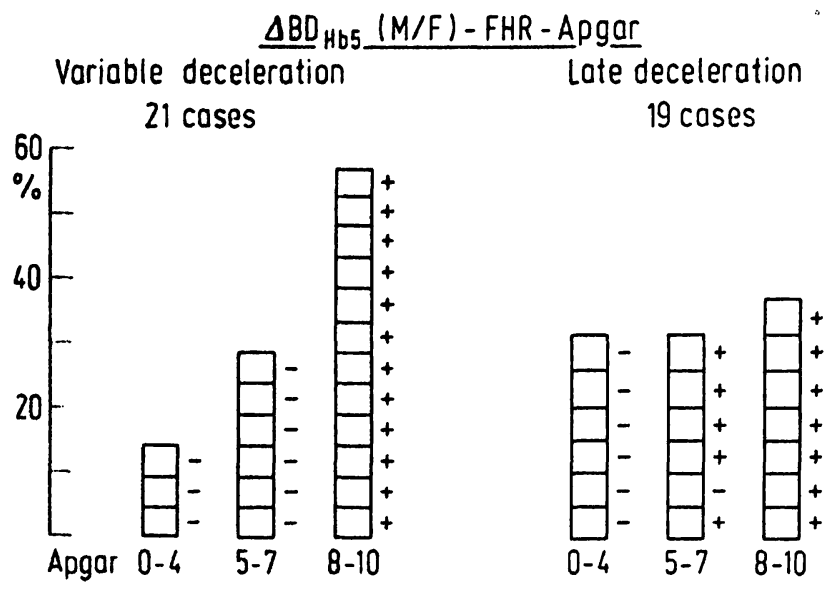

Fig. 6. $M / F \Delta B D_{H_{5}}$ in cases of variable and late decelerations, subdivided according to Apgar scorc 90 seconds after birth

$$
\begin{array}{r}
+: \mathrm{M} / \mathrm{F} \Delta \mathrm{BD}_{\mathrm{H}_{b_{5}}} \geqq 0 \\
-: \mathrm{M} / \mathrm{F} \Delta \mathrm{BD}_{\mathrm{H} \mathrm{b}_{5}}<0
\end{array}
$$

scores (APGar 5-7) were found to occur with both positive and negative values (Fig. 6).

Further evidence that fetal acidosis is due to hypoxia when the $\mathrm{M} / \mathrm{F} \triangle \mathrm{BD}_{\mathrm{H}_{5}}$ is negative is provided by the distribution of the latter values in relation to $\mathrm{Hb}$ oxygen saturation in fetuses presenting with marked bradycardia. If cases of late deceleration in our own series are classified by degree of $\mathrm{Hb}$ oxygen saturation, the $\mathrm{M} / \mathrm{F} \triangle \mathrm{BD}_{\mathrm{H} \mathrm{b}_{5}}$ is invariably positive whenever oxygen saturation is within normal limits. Negative values are encountered only in the presence of fetal hypoxia ( $\mathrm{O}_{2}$ saturation less than $1 \mathrm{SD}$ of normal cases) (Tab. VI).

Tab. VI. Correlation between $\mathrm{M} / \mathrm{F} \Delta \mathrm{BD}_{\mathrm{H}_{\mathrm{b}}}$ and fetal $\mathrm{Hb}$

\begin{tabular}{|c|c|c|c|}
\hline & Late & celeration & Normal labor \\
\hline & $\begin{array}{l}\text { Sat. } \mathrm{O}_{2} \\
<29.2 * *\end{array}$ & $\begin{array}{c}\text { Sat. } \mathrm{O}_{2} \\
\geqq 29.2^{* *}\end{array}$ & $\begin{array}{c}\text { Sat. } \mathrm{O}_{2} \\
40.1 \pm 10.9 *\end{array}$ \\
\hline $\begin{array}{l}\text { No. of } \\
\text { cases } \\
\mathrm{M} / \mathrm{F}\end{array}$ & 22 & $\begin{array}{r}15 \\
?\end{array}$ & 54 \\
\hline$\triangle \mathrm{BD}_{\mathrm{H}}$ & $\begin{array}{c}0.8 \pm 3.1 * \\
(10)\end{array}$ & $\begin{array}{c}4.1 \pm 2.3^{*} \\
(0) \text { L }\end{array}$ & $\left.\underbrace{4.0 \pm}\right|^{2.8^{*}}$ \\
\hline & & NS & \\
\hline & & $\mathrm{p}<0.001$ & \\
\hline
\end{tabular}
oxygen saturation in cases with late decelerations.

In brackets: number of cases with $\mathrm{M} / \mathrm{F} \Delta \mathrm{BD}_{\mathrm{H} \mathrm{b}_{5}}<0$ (see text).

* mean value $\pm \mathrm{SD}$

** 29.2 is the mean value of $\mathrm{Hb}$ oxygen saturation $-1 \mathrm{SD}$ in normal cases

NS $=$ not significant 


\subsubsection{Technical observations}

There have been doubts in the past regarding the clinical applicability of a parameter such as the $\mathrm{M} / \mathrm{F} \triangle \mathrm{BD}_{\mathrm{H}} \mathrm{b}_{5}$, since the test takes longer than the exigencies of the delivery room allow [32].

If the buffer line is drawn on the SiggaARDANDERSEN nomogram by the double equilibrium technique [35] or by the SALING method [30] (pHqu 40 and $\mathrm{Hb}$ ), it is in fact necessary to correct the $\mathrm{BD}$ for $\mathrm{Hb}$ oxygen saturation [38]. Having thus obtained the actual $\mathrm{P}_{\mathrm{CO} 2}$, it is then necessary to read off the $\mathrm{BD}$ data at the predetermined $\mathrm{Hb}$ level of $5 \mathrm{~g} / 100 \mathrm{ml}$ (Fig. 3). The procedure is considerably simplified and hence much faster (sufficiently fast for use in the delivery room) if reliable values for the actual $\mathrm{pH}$ and the $\mathrm{P}_{\mathrm{CO} 2}$ can be obtained directly. The $\mathrm{BD}_{\text {н }} \mathrm{b}_{5}$ of both mother and fetus can then be read off instantly from the

'SiggaARD-ANDERSEN nomogram (36) (Fig. 7).

\section{Clinical observations}

The fact that "falsely abnormal" cases do occur necessitates further diagnostic measures to establish the true condition of the fetus. Whenever the FHR is abnormal and the $\mathrm{pH}$ indicates acidosis, steps must be taken to ascertain the cause (i. e. hypoxic or maternogenic) of the acidosis.

It should be emphasized that this differentiation must be as precise as possible, since it represents the final stage of diagnosis and consequently is not subject to subsequent check. Thus, it directly determines the further obstetric management of labor. The safest of the various parameters suggested so far appears to be the $M / F \triangle B D_{\mathrm{H}_{5}}$. The most obvious clinical result of using this instead of the other parameters is the marked

\section{Summary}

FHR monitoring and microanalysis of fetal blood are mutually complementary procedures, and optimal knowledge of the fetal state is achieved by making use of both, the former for the preliminary screening of all cases at risk and the latter for the purpose of deciding on obstetric management where pathological changes are evident in the FHR.

The major difficulty in obtaining a precise value for the fetal acid-base balance lies in the occurence of "falsely abnormal" cases, i. e. cases in which the fetal pH falls during labor but the clinical condition at birth is good (APGAR $\geqq 7$ ). In our own series the incidence of such cases among fetuses at risk was $11.2 \%$ (Tab. I).

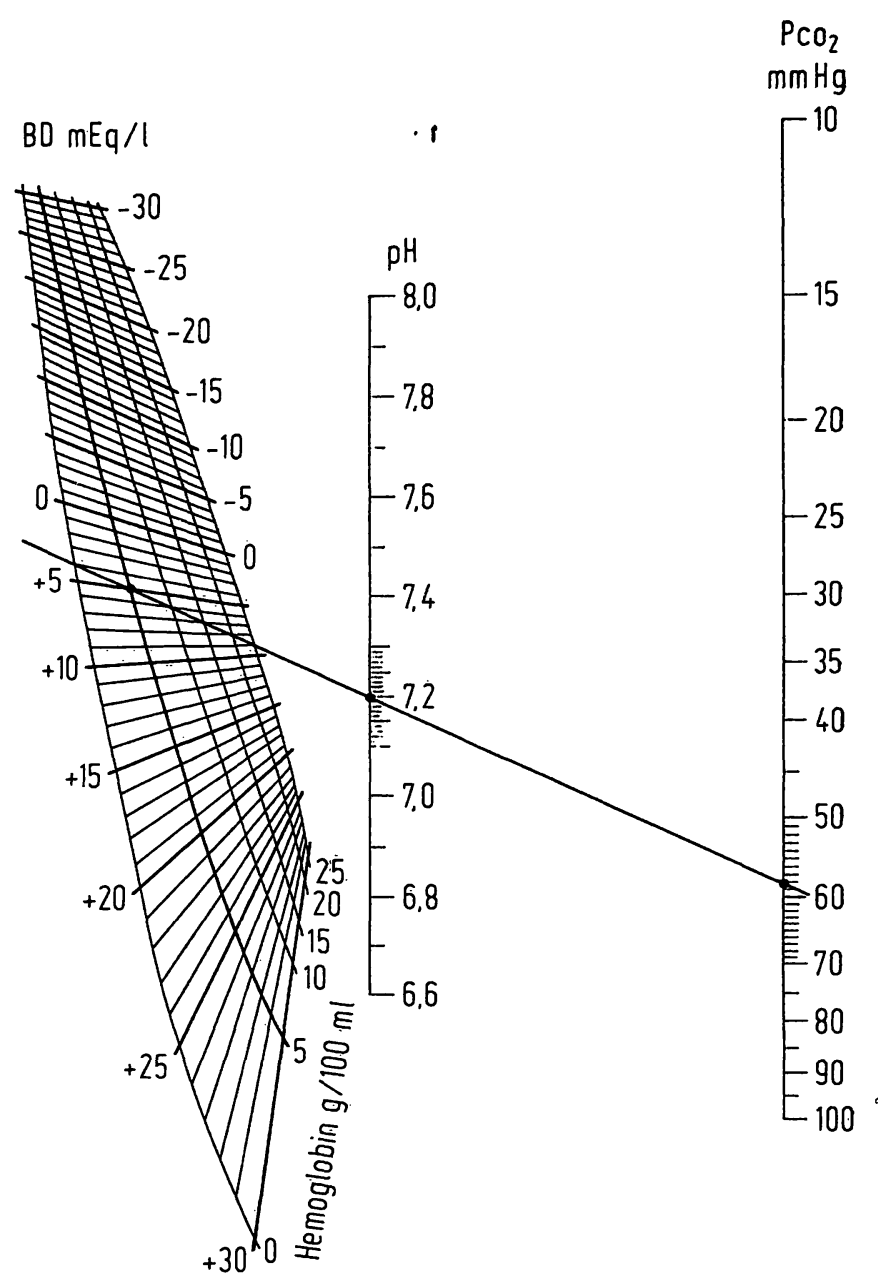

Fig. 7. Calculation of $\mathrm{BD}_{\mathrm{H}_{5}}$ from the SIgGAARD-ANDERsEN nomogram. Actual $\mathrm{pH}=7.20, \mathrm{P}_{\mathrm{CO}_{2}}=58 \mathrm{mmHg}$, $\mathrm{BD}_{\mathrm{H} \mathrm{b}_{5}}=5 \mathrm{mEq} / \mathrm{l}$

decrease in the number of erroneously diagnosed cases of fetal distress, particularly during the final stage of labor, and hence in the number of operative interventions. As has been said elsewhere [31], such a decrease is by no means to be excluded from the goals of perinatal medicine.

In the majority of these cases the fetal acidosis is thought to be a result of increased metabolic acidosis in the mother (maternogenic fetal metabolic acidosis).

The importance of the maternogenic fetal acidosis during labor lies in the fact that unless it is recognised, rapid extraction of the fetus will appear necessary on clinical grounds, although it is in fact unnecessary, since this form of acidosis has no adverse effect on the fetus.

Various parameters have been proposed for the differential diagnosis of the maternogenic fetal acidosis. These include the feto-maternal difference in base deficit ( $F / M \quad \triangle B D)$, the materno-fetal differences in pHqu $40(\mathrm{M} / \mathrm{F} \Delta \mathrm{pHqu} 40)$ the materno-fetal difference actual $\mathrm{pH}(\mathrm{M} / \mathrm{F}$ actual $\Delta \mathrm{pH})$, 
and the materno-fetal difference in base deficit of the extracellular fluid (M/F $\left.\Delta \mathrm{BD}_{\mathrm{Hb}}\right)$.

A critical analysis of thesc parameters has been carried out on the results of microtests performed during a 5 year period (1968-1972) at the First Clinic of Obstetrics and Gynecology of Milan University. The cases comprised 59 regarded as normal (normal course of pregnancy, spontancous commencement of labor at term, clear amniotic fluid, regular FHR, spontaneous birth, APGAR at $90 \mathrm{sec}$ between 8 and 10, weight at birth $>2500 \mathrm{~g}$ ), and 335 considered to be at risk (maternal disease, presence of meconium stained amniotic fluid and/or abnormal changes in FHR).

In all of these cases the FHR was recorded by cardiotokography, and the tracings were interpreted according to HoN. Microsamples of blood were taken from both mother and fetus during labor and the following determinations were carried out: actual pH, pHqu 40, Hb concentration, hemoglobin oxygen saturation, base deficit $\mathrm{Hb} 5\left(\mathrm{BD}_{\mathrm{Hb}_{5}}\right)$. The maternofetal differences were then calculated. The same determinations were carried out on samples of maternal blood and of arterial and venous cord blood taken immediately after delivery.

The clinical condition of the infant was evaluated by the Apgar score at 90 seconds after birth.

Methods for the diagnosis of maternogenic fetal acidosis

\section{Feto-maternal $\Delta \mathrm{BD}: \mathrm{F} / \mathrm{M} \Delta \mathrm{BD}$}

The use of this parameter poses certain problems, in that the $\mathrm{BD}$ is not corrected for the HB oxygen saturation, and it cannot therefore be expected to provide an accurate comparison of the metabolic components of the maternal and fetal acid-base balance. The fetal BD appears higher (by $2.2-4.8 \mathrm{mEq} / 1$ for normal $\mathrm{Hb}$ and oxygen saturation levels of fetal blood) than the true value, and hence higher than the maternal value (Fig. 1).

2 Difference between maternal and fetal pHqu 40 values: $\mathrm{M} / \mathrm{F} \Delta \mathrm{pHqu} \mathbf{4 0}$

According to SALING a materno-fetal difference of less than $0.05 \mathrm{pH}$ units indicates that fetal acidosis during labor is of maternal origin. The parameter is quickly and easily obtainable, but has the same disadvantages as the $F / M$ $\triangle B D$ (Fig. 1).

3 Difference between the actual $\mathrm{pH}$ values of mother and of fetus: $M / F$ actual $\Delta \mathrm{pH}$

The use of the $\mathrm{M} / \mathrm{F}$ actual $\Delta \mathrm{pH}$ has been suggested in order to overcome the difficulty arising from the fact that the mean fetal $\mathrm{pH}$ during labor varies from one maternity unit to another. The substitution of the $\mathrm{M} / \mathrm{F}$ actual $\Delta \mathrm{pH}$ for the fetal actual $\mathrm{pH}$ would provide a solution to the problem of recognizing maternogenic fetal metabolic acidosis. In practice, however, this does not seem to be possible, since $\mathrm{pH}$ is logarithmic, and the same concentration of hydrogen ions may therefore be expressed by very different $\Delta \mathrm{pH}$ values and vice versa (Tab. II).

Moreover, close correlation between the $M / F$ actual $\Delta \mathrm{pH}$ and the degree of fetal oxygenation as assessed by fetal scalp blood $\mathrm{P}_{\mathrm{O}_{2}}$ has not been confirmed (Tab. III).

4 Difference between maternal and fetal base deficits of the extracellular fluid: $M / F \Delta B_{H b_{5}}$

Base deficit of the extracellular fluid $\left(\mathrm{BD}_{\mathrm{Hb}_{5}}\right)$

Any valid comparison between the metabolic components of the maternal and fetal acid-base balance requires not only correction for the hemoglobin $\mathrm{O}_{2}$-saturation but also subsequent correction of the false increase in $\mathrm{BD}$ encountered in vivo in hypercapnia, a condition that is almost the rule rather than the exception in the fetus during labor. The increase in the concentration of $\mathrm{CO}_{2}$, and hence of bicarbonate, in the peripheral blood causes the bicarbonate to move into the interstitial fluid, with a consequent increase in the $\mathrm{BD}$ of the peripheral blood (Fig. 2). In order to prevent variations in $\mathrm{PCO}_{2}$ from being reflected in the BD, SIGGAARDANDERSEN has suggested using the $B D$ of the extracellular fluid, which may be determined from the amount of red cells distributed throughout the interstitial space, i. e. at a hemoglobin concentration of $5 \mathrm{~g} / 100 \mathrm{ml}\left(\mathrm{BD}_{\mathrm{Hb}_{5}}\right)$ (Fig. 3).

\section{Materno-fetal $\triangle \mathbf{B D}_{\mathrm{Hb}_{5}}$ in normal labor}

According to JACOBSON the fetal $\mathrm{BD}_{\mathrm{H} \mathrm{B}_{5}}$ remains below the maternal value during normal labor, particularly during expulsion. Our own series confirmed this finding: the mean $\mathrm{M} / \mathrm{F} \Delta \mathrm{BD}_{\mathrm{H} b_{5}}$ during normal labor was $+4.0 \mathrm{mEq} / 1 \pm 2.8$ (SD).

Recognition of falsely abnormal cases by means of the $\mathbf{M} / \mathbf{F} \Delta \mathbf{B D}_{\mathbf{H b}_{5}}$

We have confirmed that a maternogenic etiology of fetal acidosis can be detected in "falsely abnormal" cases by the $\mathbf{M} / \mathbf{F} \Delta \mathbf{B D}_{\mathrm{Hb}_{5}}$.

For this purpose a positive value of $\mathrm{M} / \mathrm{F} \Delta \mathrm{BD}_{\mathrm{Hb}_{5}}$ in the presence of a low $\mathrm{pH}$ is regarded as indicating normal placental function, and hence pointing to the maternal origin of the acidosis. A value of zero corresponds approximately to the mean materno-fetal $\triangle \mathrm{BD}_{\mathrm{H}_{5}}$ minus $11 / 2 \mathrm{SD}(4.0-4.2 \mathrm{mEq} / \mathrm{l})$ for normal cases.

In a series of 179 cases at risk, the value of $\mathrm{M} / \mathrm{F} \Delta \mathrm{BD}_{\mathrm{H} \mathrm{b}_{5}}$ was positive in $79.4 \%$ of the "falsely abnormal" cases (actual $\mathrm{pH}<7.25$, APGAR $\geqq 7$ ), including $84 \%$ of cases of preacidosis (actual pH 7.25-7.20) and $75 \%$ of cases of frank acidosis $(\mathrm{pH}<7.20)$ (Tab. IV).

If instead, the materno-fetal $\Delta \mathrm{pHqu} 40$ parameter had been used, the maternal origin of the acidosis would have been recognised in a lower percenttage of cases, i. e. $35.9 \%$ of fetuses having an actual $\mathrm{pH}<7.25,52.6 \%$ with a $\mathrm{pH}$ between 7.25 and 7.20 , and $20 \%$ of those with actual $\mathrm{pH}$ $<7.20$ (Tab. IV).

In our own series using the materno-fetal $\Delta \mathrm{pHqu} 40$ as the parameter, the incidence of maternogenic fetal metabolic acidosis during labor was $8.5 \%$ in the first stage and $28 \%$ in the second stage of labor. With the $\mathrm{M} / \mathrm{F} \triangle \mathrm{BD}_{\mathrm{Hb}}$, on the other hand, the percentages increased to $64.4 \%$ and $66.7 \%$ respectively (Tab. V).

This difference in the ability of the two indices to allow recognition of maternogenic fetal acidosis is of consider- 
able clinical importance, since this directly determines the future management of labor.

Correlation between materno-fetal $\Delta \mathbf{B D}_{\mathrm{Hb}}$ and $\Delta \mathrm{pH}$ qu 40

The differing results obtained with the two methods do not agree with the good statistical correlation between the parameters, which was high in the series recently reported: $r=0.98$ [33] and $r=0.80$ (Fig. 4). Further examination of the correlation shows, however, that a materno-fetal $\Delta$ pHqu $40 \leqq 0.05$ rules out fetal hypoxia as the cause of the acidosis, whereas a value $>0.05$ does not necessarily exclude a maternogenic etiology (Fig. 5).

Prognostic value of materno-fetal $\Delta \mathrm{BD}_{\mathrm{H}_{5}}$ in the presence of changes in FHR during labor

In cases showing abnormal changes in the FHR (variable and late decelerations) during the 90 minutes preceding delivery, the materno-fetal $\triangle \mathrm{BD}_{\mathrm{H} \mathrm{b}_{5}}$ was negative in all of our cases that subsequently were graded with $\leqq 4$ APGAR score, and positive in those that were scored $\geqq 8$. The cases in which the APGAR score range 5-7 included both : positive and negative values (Fig. 6). If the late decelera- tions are divided according to $\mathrm{Hb}$ oxygen saturation, it can be seen that when the latter is within normal limits the materno-fetal $\triangle B D_{H_{b}}$ is positive. Negative values of $\mathrm{M} / \mathrm{F} \triangle \mathrm{BD}_{\mathrm{Hb}_{5}}$ occur only in fétal hypoxia (Tab. VI).

\section{Conclusions}

The results described above appear to indicate that:

1. the metabolic component of fetal acid-base balance is reflected more accurately in the $\mathrm{BD}_{\mathrm{H} \mathrm{b}_{5}}$ than in pHqu 40 or the uncorrected BD;

2. in the diagnosis of maternogenic fetal acidosis, the materno-fetal $\triangle B D_{\mathrm{Hb}_{5}}$ is a more reliable test than the $\Delta \mathrm{pHqu} 40$, despite the close statistical correlation between the two.

When the actual fetal $\mathrm{pH}$ during labor is found to be below, subsequent recognition of the fetal acidosis as being maternal in origin allows for a decision against rapid extraction of the fetus. Any decrease in the number of cases requiring intervention will increase with the accuracy of the parameter used to compare the metabolic components of maternal and fetal acid-base balance.

Keywords: Acid-base balance, base-deficit $\mathrm{Hb} 5\left(\mathrm{BD}_{\mathrm{H}_{\mathrm{b}}}\right)$, bradycardia, $\Delta \mathrm{BD}_{\mathrm{Hb}}(\mathrm{M} / \mathrm{F}), \Delta \mathrm{pHqu} 40(\mathrm{M} / \mathrm{F}), \Delta \mathrm{pHact}(\mathrm{M} / \mathrm{F})$, fetal-blood-analysis, fetus, heart-rate-monitoring, labor, maternogenic fetal acidosis, $\mathrm{pH}$.

\section{Zusammenfassung}

Erkennung und Bedeutung der maternogenen fetalen Azidose während der Intensivüberwachung der Geburt.

Die Überwachung des fetalen Herzschlages und die Fetalblut-Analyse sind sich ergänzende Überwachungsmethoden; ein optimaler Einblick in die augenblickliche Situation des Feten wird durch den Einsatz beider Methoden ermöglicht: die erstere für ein vorläufiges Herausfiltern aller Risikofälle und die letztere, um geburtshilfliche Entscheidungen herbeizuführen, wenn pathologische Veränderungen der fetalen Herzschlagfrequenz auftreten.

Die Hauptschwierigkeit bei der Beurteilung des fetalen Säure-Basen-Haushaltes liegt im Auftreten von „falsch pathologischen" Fällen, d. h. von Fällen, in denen der $\mathrm{pH}$-Wert während der Geburt absinkt, der klinische $\mathrm{Zu}$ stand bei der Geburt jedoch gut ist (APGAR $\geqq 7$ ). In unserer eigenen Untersuchungsreihe war die Häufigkeit solcher Fälle unter den Risikofällen 11,2\% (Tab. I).

In der Mehrzahl dieser Fälle kann man davon ausgehen, daß die fetale Azidose Folge einer erhöhten metabolischen Azidität der Mutter ist (maternogene fetale metabolische Azidose).

Die Bedeutung der maternogenen fetalen Azidose während der Geburt beruht auf der Tatsache, daß, wenn sie nicht erkannt wird, eine schnelle Entwicklung des Feten aufgrund von klinischen Hinweisen notwendig erscheint, obwohl diese rasche Entwicklung in Wirklichkeit nicht notwendig ist, weil diese Form der Azidose keinen schädlichen Einfluß auf den Feten hat.
Es wurden verschiedene Parameter vorgeschlagen für die Differentialdiagnose der maternogenen fetalen Azidose; diese schließen ein: die feto-maternale Differenz hinsichtlich des Basen-Defizits (F/M $\triangle \mathrm{BD}$ ), materno-fetale Unterschiede im pHqu40 (M/F $\triangle \mathrm{pH}$ qu40, materno-fetale Differenz des aktuellen $\mathrm{pH}(\mathrm{M} / \mathrm{F} \Delta \mathrm{pHakt}$.) und die materno-fetale Differenz hinsichtlich des Basen-Defizits der extrazellulären Flüssigkeit ( $\left.\mathrm{M} / \mathrm{F} \triangle \mathrm{BD}_{\mathrm{Hb}_{5}}\right)$.

Eine kritische Analyse dieser Parameter wurde anhand der Ergebnisse von Miktoblutuntersuchungen im Verlauf der Jahre 1968-1972 an der Ersten Geburtshilflichen und Gynäkologischen Klinik an der Universität Mailand durchgeführt. Die Fälle umfaßten 59 normale Geburten (normaler Schwangerschaftsverlauf, spontaner Wehenbeginn am Termin, klares Fruchtwasser, unauffällige fetale Herzschlagfrequenz, Spontangeburt, APGAR nach 90 Sekunden zwischen 8 und 10 , Geburtsgewicht über $2500 \mathrm{~g}$ ) und 335 Risikogeburten (mütterliche Erkrankungen, grünes Fruchtwasser und/oder abnorme Herzschlagfrequenz-Kurven).

In allen diesen Fällen wurde die Herzschlagfrequenz durch Kardiotokographie überwacht, und die Herzschlagfrequenzmuster wurden in Anlehnung an HoN bewertet. Mikroblutproben wurden von Mutter und Fet während der Geburt entnommen; die folgenden Bestimmungen wurden durchgeführt: pHakt., pHqu40, Hb, Sauerstoffsättigung des $\mathrm{Hb}$, Basen-Defizit $\mathrm{Hb} 5$ (BD $\left.\mathrm{Hb}_{5}\right)$. Es wurden dann die maternofetalen Differenzen berechnet. Die gleichen Bestimmungen wurden im mütterlichen Blut und im Blut von Nabelschnurarterie und -vene unmittelbar nach der Geburt durchgeführt. 
Der klinische Zustand der Kinder wurde entsprechend dem APGAR-Score 90 Sekunden nach der Geburt bewertet.

Methoden für die Diagnose der maternogenen fetalen Azidose.

\section{Der feto-maternale $\Delta \mathrm{BD}: \mathrm{F} / \mathrm{M} \Delta \mathrm{BD}$}

Dic Verwendung dieses Parameters ist insofern problematisch, als der BD nicht auf die reale Sauerstoffsättigung des Hämoglobin korrigiert ist und demzufolge auch nicht erwart et werden kann, daß er einen präzisen Vergleich der metabolischen Komponenten des mütterlichen und fetalen Säure-Basenhaushalts ermöglicht. Der fetale BD (Basendefizit) liegt scheinbar höher (um 2,2 bis $4,8 \mathrm{mÄq} / \mathrm{l}$ bei normalem Hämoglobingehalt und normaler Sauerstoffsättigung des fetalen Blutes) als der wirkliche Wert und demzufolge auch höher als der mütterliche Wert (Fig. 1).

2 Unterschiede zwischen mütterlichen und fetalen pHqu 40-Werten: M/F $\Delta$ pHqu 40

Nach SAlING bedeutet eine materno-fetale Differenz von weniger als 0,05 pH-Einheiten, daß die fetale, subpartuale Azidose maternogenen Ursprungs ist. Der Parameter kann schnell und leicht bestimmt werden, hat jedoch dieselben Nachteile wie der F/M $\triangle B D$ (Fig. 1).

3 Unterschied zwischen den aktuellen pH-Werten der Mutter und dem Feten: $\mathbf{M} / \mathbf{F} \Delta \mathbf{p H}$ akt

Um die Schwierigkeit zu überwinden, daß das mittlere fetale $\mathrm{pH}$ sub partu von einem Klinikum zum anderen Schwankungen zeigt, wurde $\operatorname{der} \mathrm{M} / \mathrm{F} \Delta \mathrm{pH}$ akt eingeführt und verwendet.

Es war zu vermuten, daß der Austausch des aktuellen fetalen $\mathrm{pH}$ gegen den $\mathrm{M} / \mathrm{F} \Delta \mathrm{pH}$ akt eine Lösung des Problems der Erkennung der maternogenen fetalen metabolischen Azidose mit sich bringen würde. Dies scheint in praxi jedoch nicht möglich zu sein, da der pH-Wert eine logarithmische Größe ist und gleiche Wasserstoffionenkonzentrationen demzufolge durch sehr unterschiedliche $\Delta \mathrm{pH}$ Werte dargestellt werden können und vice versa (Tab. II). Darüberhinaus konnte keine gute Korrelation zwischen $\operatorname{dem} M / F \Delta \mathrm{pH}$ aktuell und dem Grad der fetalen Oxygenation gesichert werden (Tab. III).

4 Unterschied zwischen mütterlichem und fetalem Basendefizit im extrazellulären Raum: $\triangle B D_{\mathrm{H}_{5}}$

Das Basendefizit im extrazellulären Raum (BD Hb $_{5}$ ) Jeder brauchbare Vergleich zwischen dem metabolischen Komponenten des mütterlichen und fetalen Säure-Basenhaushaltes schließt nicht nur die Korrektur auf die reale Sauerstoffsättigung des Hämoglobin ein, sondern auch anschließend die Korrektur auf die hyperkapniebedingte vorgetäuschte Zunahme des BD in vivo - ein Zustand, der beim Feten unter der Geburt fast normalerweise gegeben ist. Die Zunahme der $\mathrm{CO}_{2}$-Konzentration und damit auch des Bikarbonat im peripheren Blut veranlaßt das Bikarbonat, in den interstitiellen Raum zu diffundieren, was einen Anstieg des BD im peripheren Blut zur Folge hat (Fig. 2). $\mathrm{Um}$ den $\mathrm{BD}$ unabhängig von $\mathrm{PCO}_{2}$-Veränderungen zu machen, schlug SrggaARD-ANDERSEN das Basendefizit im extrazellulären Raum vor, das bestimmt werden kann, wenn man sich die roten Blutkörperchen über den gesamten interstitiellen Raum gleichmäßig verteilt denkt, d. h. bei einer Hämoglobinkonzentration von $5 \mathrm{~g} / 100 \mathrm{ml}\left(\mathrm{BD}_{\mathrm{Hb}_{5}}\right)$ ) (Fig. 3).

Mütterlich-fetale $\Delta \mathrm{BD}_{\mathrm{Hb}_{5}}$-Werte bei normaler Wehentätigkeit

Nach JAcoBson bleiben die fetalen $\mathrm{BD}_{\mathrm{H}_{5}}$-Werte unter jenen der Mutter bei normaler Wehentätigkeit und besonders auch in der Austreibungsperiode. Unsere eigenen Untersuchungen bestätigen diesen Befund: der mittlere $\triangle \mathrm{BD}_{\mathrm{Hb}}$ bei normaler Wehentätigkeit lag bei $+4,0 \mathrm{mÄq} / \mathrm{l}$ $\pm 2,8(\mathrm{SD})$.

Erkennen von falsch abnormalen Fällen mit Hilfe des $\mathrm{M} / \mathrm{F} \Delta \mathrm{BD}_{\mathrm{Hb}}$

Wir konnten zeigen, daß die mütterliche Ursache einer fetalen Azidose in falsch abnormalen Fällen mit Hilfe des $\mathbf{M} / \mathbf{F} \Delta \mathbf{B D}_{\mathrm{H}_{b_{5}}}$ aufgedeckt werden kann. Zweckmäßigerweise wird ein positiver $\Delta \mathrm{pH}_{\mathbf{H}} \mathrm{b}_{5}$ in Gegenwart eines tiefen (fetalen) $\mathrm{pH}$-Wertes als Indikator für eine normale Plazentafunktion und demzufolge als ein Hinweis für den mütterlichen Ursprung der Azidose angesehen. Ein Wert von Null entspricht ungefähr dem mittleren maternofetalen $\triangle \mathrm{BD}_{\mathrm{Hb}_{5}}-1 \frac{1}{2} \mathrm{SD}(4,0 \mathrm{mÄq} / 1-4,2)$ bei Normalfällen. Bei 179 Risikofällen war der M/F $\triangle B D_{\mathrm{Hb}_{5}}$ in $79,4 \%$ positiv bei den falsch abnormalen Fällen (aktuelles $\mathrm{pH}<7,25$, APGAR $\geqq 7$ ), in $84 \%$ der Fälle mit Präazidose (aktueller pH $7,25-7,20)$ und in $75 \%$ der Fälle mit klarer Azidose ( $\mathrm{pH}$ $<7,20$ ) (Tab. IV).

Mit dem materno-fetalen $\Delta \mathrm{pHqu} 40$ würde der mütterliche Ursprung der Azidose in einem geringeren Prozentsatz der Fälle diagnostiziert worden sein, nämlich bei $35,9 \%$ der Feten mit einem $\mathrm{pH}$ von $<7,25$, in $52,6 \%$ mit einem $\mathrm{pH}$ Wert zwischen 7,25 und 7,20 und in $20 \%$ bei jenen Feten mit aktuellen pH-Werten unter 7,20 (Tab. IV). Die Häufigkeit der maternogenen fetalen metabolischen Azidose sub partu lag mit der Meßgröße des maternofetalen $\Delta \mathrm{pHqu} \mathbf{4 0}$ bei unserem eigenen Material bei $8,5 \%$ in der Eröffnungsperiode und bei $28 \%$ in der Austreibungsperiode, mit dem Parameter $\mathrm{M} / \mathrm{F} \Delta \mathbf{B D}_{\mathrm{H}} \mathrm{b}_{5}$ dagegen stiegen diese Prozentsätze an auf $64,4 \%$ bzw. 66,7\% (Tab. V). Diese Differenz der Eignung der beiden indices für die Erkennung einer maternogenen fetalen Azidose ist von gewisser klinischer Bedeutung, da diese die zukünftige Geburtsleitung direkt bestimmend beeinflußt.

Korrelation zwischen dem materno-fetalen $\Delta \mathbf{B D}_{\mathrm{Hb}}$ und $\Delta$ pHqu 40

Die mit den beiden Methoden gewonnenen unterschiedlichen Resultate harmonieren nicht mit den guten statistischen Korrelationen der beiden Parameter untereinander: der Koeffizient lag bei den kürzlich mitgeteilten Serien mit $r=0,98$ (33) und $r=0,80$ (Fig. 4) recht hoch. Eine eingehende Prüfung der Korrelationen zeigt jedoch, da $\beta$ ein materno-fetaler $\Delta \mathrm{pHqu} 40<0,05$ ein fetale 
Hypoxie als Azidoseursache anzeigt, daß jedoch ein Wert von $>0,05$ eine maternogene Ursache nicht notwendigerweise ausschließt (Fig. 5).

Der prognostische Wert des materno-fetalen $\triangle B D_{\text {Hb }}$ beim Vorliegen von fetalen Herzfrequenzalterationen sub partu

Bei jenen Fällen mit Herzfrequenzalterationen (variable und späte Dezelerationen während des 90-Minuten-Intervalles vor der Geburt) und mit einer APGAR-Zahl von $\leqq 4$ war der materno-fetale $\triangle \mathrm{BD}_{\text {H }}$ 足 negativ, bei jenen Fällen mit APGAR $\geqq 8$ war er positiv. Fälle, die zwischen APGAR 5 und 7 rangierten, wiesen sowohl positive wie negative Werte auf (Fig. 6).

Trennt man die Fälle mit Spätdezelerationen auf hinsichtlich der Sauerstoffsättigung des fetalen Hämoglobins, so zeigt sich, daß der materno-fetale $\triangle \mathrm{BD}_{\mathrm{H} \mathrm{b}_{5}}$ positiv ist in jenen Fällen mit diesbezüglich normalen Werten.

Negative Werte des $\mathrm{M} / \mathrm{F} \Delta \mathrm{BD}_{\mathrm{H} \mathrm{b}_{5}}$ kommen nur bei fetaler Hypoxie vor (Tab. VI).

' Schlüsselwörter: Basendefizit, Bradycardie, Dezeleration, Fetalblutanalyse, Fetus, Herzschlagfrequenz, maternogene fetale Azidose, Säure-Basen-Haushalt, Wehen.

\section{Résumé}

Diagnostic et signification de l'acidose métabolique foetale maternogénique dans le travail

Le contrôle FHR et la microanalyse du sang foetal sont des procédés réciproquement complémentaires qui permettent d'étudier au maximum l'état foetal, le premier en détectant tous les cas menacés et la deuxième pour décider du traitement obstétrical là où se manifestent des altérations pathologiques dans le FHR.

La difficulté majeure pour obtenir une valeur précise pour l'équilibre acidobasique foetal réside dans l'apparition de cas „faussement anormaux", c. à. d. de cas où le pH foetal tombe durant le travail, mais où la condition clinique s'avère bonne à la naissance (APGAR $\geqq 7$ ). Dans nos propres séries d'observations, l'incidence de tels cas parmi les foetus menacés s'est chiffrée à $11,2 \%$ (Tab. I).

Dans la majorité de ces cas, l'acidose foetale est supposée résulter d'une acidose métabolique accrue chez la mère (acidose métabolique foetale maternogénique). L'importance de cette acidose foetale maternogénique durant le travail réside dans le fait qu'à moins de la reconnaître, il paraît nécessaire de procéder à une extraction rapide du foetus pour des raisons cliniques bien que cela soit inutile en réalité puisque cette forme d'acidose n'a pas d'effet néfaste sur le foetus.

Des paramètres variés ont été proposés pour le diagnostic différentiel de l'acidose foetale maternogénique. Ils incluent la différence foeto-maternelle dans le déficit basique (F/M$\triangle \mathrm{BD}$ ), les différences materno-foetales dans le $\mathrm{pHqu} 40$ $(\mathrm{M} / \mathrm{F} \Delta \mathrm{pHqu} 40)$, la différence materno-foetale $\mathrm{pH}$ actuel $(\mathrm{M} / \mathrm{F} \Delta \mathrm{pHactuel})$, et la différence materno-foetale dans le déficit basique du liquide extracellularie (M/F $\left.\triangle B D_{H_{6}}\right)$.

Une analyse critique de ces paramètres a été effectuée sur les résultats de microtests étagés sur une période de 5 ans (1968

\section{Schlußfolgerungen}

1. die metabolische Komponente im fetalen SäureBasenhaushalt präziser durch den $\mathrm{BD}_{\mathrm{Hb}}$ beschrieben wird als durch den pHqu 40 oder den unkorrigierten Basenexzeß;

2. für die Diagnose einer maternogenen fetalen Azidose der maternofetale $\Delta \mathrm{BD}_{\mathrm{H} \mathrm{b}_{5}}$ eine zuverlässigere Testgröße ist als der $\Delta$ pHqu 40 trotz der engen statistischen Korrelationen zwischen den beiden Größen.

Die Erkenntnis, daß beim Vorliegen eines tiefen aktuellen $\mathrm{pH}$-Wertes unter der Geburt diese fetale Azidose maternogenen Ursprungs ist, ermöglicht die Entscheidung gegen eine rasche Extraktion des Feten. Mit der Zunahme der Genauigkeit jenes Parameters, der für den Vergleich der metabolischen Komponenten des maternalen und fetalen Säure-Basenhaushaltes zur Anwendung kommt, wird die Zahl der Fälle, die ein Eingreifen des Geburtshelfers nötig machen, abnehmen.
Die oben beschriebenen Resultate scheinen zú belegen, daß:
-1972) à la Première Clinique d'Obstétrique et de Gynécologie de l'Université de Milan. 59 de ces cas étaient considérés comme normaux (grossesse normale, déclenchement spontané du travail au terme prévu, liquide amniotique clair, FHR régulier, naissance spontanée, APGAR à $90 \mathrm{sec}$. entre 8 et 10 , poids à la naissance $>2500 \mathrm{~g}$ ) et 335 comme menacés (maladie maternelle, présence de liquide amniotique coloré de méconium et/ou changements anormaux dans le FHR.

Dans tous ces cas, le FHR a été enregistré par cardiotocographie, et les tracés ont été interprétés en HoN. Des microspécimens de sang ont été prélevés sur la mère et le foetus en cours de travail avec les calculs suivants: pHactuel, pHqu40, concentration $\mathrm{Hb}$, saturation d'oxygène de l'hémoglobine, déficit basique $\mathrm{Hb} 5\left(\mathrm{BD}_{\mathrm{Hb}_{5}}\right)$. Les différences materno-foetales ont alors été calculées. Les mêmes déterminations ont été faites sur des spécimens de sang maternel et de sang ombilical artériel et veiñeux prélevés immédiatement après l'accouchement.

La condition clinique des nouveaux-nés a été évaluée par le score APGAR à 90 secondes après la naissance.

Méthodes pour le diagnostic de l'acidose foetale maternogénique dans le travail

\section{1. $\triangle \mathrm{BD}$ materno- $\ddot{\text { foetal }}$}

L'emploi de ce paramètre pose certains problèmes du fait que le BD n'est pas corrigé pour la saturation d'oxygène de l'hémoglobine et qu'il ne peut pas, en conséquence, servir à comparer avec précision les facteurs métaLe $\mathrm{BD}$ foetal paraît plus élevé $(2,2$ à $4,8 \mathrm{mEq} / \mathrm{l}$ pour $\mathrm{Hb}$ et niveaux de saturation d'oxygène normaux du sang foetal) boliques de l'équilibre acidobasique maternel et foetal. 
que la valeur véritable, et, par conséquent, plus éléve aussi que la valeur maternelle (Fig. 1).

\section{Différence entre les valeurs pHqu 40 maternelles et} foetales: $\mathbf{M} / \mathbf{F} \Delta \mathrm{pHqu} \mathbf{4 0}$

Selon SALING, une différence materno-foetale inférieure à 0,05 unités $\mathrm{pH}$ indique que l'acidose foetale durant le travail est d'origine maternelle. Le paramètre peut être obtenu rapidement et facilement, mais présente les mêmes inconvénients que le $\mathrm{M} / \mathrm{F} \triangle \mathrm{BD}$ (Fig. 1).

3. Différence entre les valeurs $\mathrm{pH}$ actuelles de la mère et du foetus: $\mathrm{M} / \mathrm{F} \Delta \mathrm{pH}$ actuel

Le recours au $\mathrm{M} / \mathrm{F} \Delta \mathrm{pH}$ actuel a été suggéré pour remédier à la difficulté causée par le fait que le $\mathrm{pH}$ foetal moyen varie pendant le travail d'une maternité à l'autre. La substitution $\mathrm{du} \mathrm{M} / \mathrm{F} \Delta \mathrm{pH}$ actuel au $\mathrm{pH}$ actuel foetal fournirait une solution au problème du dépistage de l'acidose métabolique foetale maternogénique. En pratique néanmoins, cela ne semble pas possible, car le $\mathrm{pH}$ est logarithmique et, par conséquent, la même concentration de ions hydrogène peut être exprimée par des valeurs $\Delta \mathrm{pH}$ très différentes et vice versa (Tab. II). De plus, il n'a pas été possible de confirmer une étroite corrélation entre le $\mathrm{M} / \mathrm{F} \Delta \mathrm{pH}$ actuel et le degré d'oxygénation foetale (Tab. III).

4. Différence entre les déficits basiques maternels et foetaux du liquide extracellulaire: $M / F \Delta B D_{H_{b_{5}}}$

Déficit basique du liquide extracellulaire $\left(\mathrm{BD}_{\mathrm{Hb}_{5}}\right)$

Toute comparaison valable entre les facteurs métaboliques de l'équilibre acidobasique maternel et foetal requiert non seulement une correction pour la saturation d'oxygène de l'hémoglobine, mais aussi une correction subséquente du faux accroissement du BD rencontré in vivo dans l'hypercapnie, une condition qui est presque toujours la norme dans le foetus pendant le travail. L'augmentation de la concentration de $\mathrm{CO}_{2}$ et, par conséquent, de bicarbonate dans le sang périphérique provoque la pénétration du bicarbonate dans le liquide interstitiel, avec une hausse conséquente du $\mathrm{BD}$ du sang périphérique (Fig. 2). Afin d'empêcher que les variations $\mathrm{PCO}_{2}$ ne se reflètent sur le $\mathrm{BD}$, SiggaARD-ANDERSEN a suggéré d'utiliser le BD du liquide extracellulaire, qui peut être détérmine à partir des cellules rouges réparties dans l'espace interstitiel, c. à. d. pour une concentration de $\mathrm{Hb}$ de $5 \mathrm{~g} / 100 \mathrm{ml}$ (BD $\left.\mathrm{Hb}_{5}\right)$ (Fig. 3).

\section{$\Delta \mathbf{B D}_{\mathrm{Hb}_{5}}$ materno-foetal dans le travail normal}

Selon JAcosson, le $\mathrm{BD}_{\mathrm{Hb}_{5}}$ foetal reste au-dessous de la valeur maternelle durant le travail normal, et en particulier durant l'expulsion ainsi que l'ont prouvé nos propres observations: le $\mathrm{M} / \mathrm{F} \Delta \mathrm{BD}_{\text {H殒 }}$ moyen a été de $+4,0 \mathrm{mEq} / 1$ $\pm 2,8$ DS durant le travail normal.

Dépistage de fausses anorimalites au moyen du $M / F$ $\triangle \mathbf{B D}_{\text {Hb5 }}$

Nous avons confirmé que l'étiologie maternogénique de l'acidose foetale peut être dépistée dans les fausses anormalités par le $\mathrm{M} / \mathrm{F} \Delta \mathbf{B D}_{\mathrm{Hb}_{5}}$.
A cet effet, une valcur positive du $\mathrm{M} / \mathrm{F} \Delta \mathrm{BD}_{\mathrm{Hb}_{5}}$ en présence d'un $\mathrm{pH}$ bas est considérée comme témoignage d'une fonction placentaire normale et, en conséquence, de l'origine maternelle de l'acidose. Une valeur de zéro correspond approximativement à la valeur moyenne du $\mathrm{M} / \mathrm{F} \triangle \mathrm{BFD}_{\mathrm{Hb}_{5}}$ $-11 / 2$ DS $(4,0 \mathrm{mEq} / \mathrm{l}-4,2)$ pour les cas normaux.

Dans un groupe de 179 cas à usque, la valeur du $\mathrm{M} / \mathrm{F} \Delta \mathrm{BD}_{\mathrm{Hb}}$ a été positive dans $79,4 \%$ des fausses anormalités ( $\mathrm{pH}$ actuel $<7,25$, APGar $\geqq 7$ ), compris $84 \%$ de cas de préacidose ( $\mathrm{pH}$ actucl $7,25-7,20)$ et $75 \%$ de cas d'acidose nette $(\mathrm{pH}<7.20)$ (Tab. IV).

Avec le $\Delta \mathrm{pHqu} 40$ materno-foetal, l'origine maternelle de l'acidose aurait été reconnue dans un pourcentage moins ćlevé de cas, c. à. d. 35,9\% des foetus ayant un $\mathrm{pH}$ actuel $<7,25,52,6 \%$ avec un $\mathrm{pH}$ entre 7,25 et 7,20 , et $20 \%$ de ccux avec un $\mathrm{pH}$ actuel $<7,20$ (Tab. IV).

Dans nos propres séries, avec le $\Delta \mathrm{pHqu} 40$ materno-foetal comme paramètre, l'incidence de l'acidose métabolique foetale maternogénique durant le travail a été de 8,5\% dans la période de dilatation et de $28 \%$ dans la deuxième phrase; avec le $M / F \Delta B_{H_{b}}$, d'autre part, les pourcentages se sont éléves respectivement à $64,4 \%$ et $66,7 \%$ (Tab. V). La différence de capacité des deux indices pour le dépistage de l'acidose foetale maternogénique est de remarquable importance clinique, puisqu'elle détermine directement la conduite future du travail.

\section{Corrélation entre le $\Delta \mathrm{BD}_{\mathrm{Hb}}$ et le $\Delta \mathrm{pHqu} 40$ materno-} foetal

Les résultats différents obtenus avec les deux méthodes ne concordent pas avec la bonne corrélation statistique entre ces paramètres, correlation qui est très élevée dans les séries communiquées récenment: $\mathrm{r}=0,98$ [33] te $\mathrm{r}=0,80$ (Fig. 4). Un examen ultérieur de la corrélation montre, néanmoins, qu'un $\Delta$ pHqu $40 ₹ 0,05$ materno-foetal élimine l'hypoxie foetale comme cause éventuelle de l'acidose, tandis qu'une valeur $>0,05$ n'exclut pas necessairement une étiologie maternogénique (Fig. 5).

Valeur de pronostic du $\Delta B D_{\mathrm{Hb}_{5}}$ materno-foetal en présence de changements du le FHR durant le travail

Dans les cas présentant des changements du FHR décélerations variables et tardives durant les 90 minutes précédant l'accouchement), le $\mathbf{\Delta} \mathbf{B D}_{\mathrm{Hb}_{5}}$ materno-foetal a été dans nos séries: a) négatif dans les cas classés par la suite comme APGAR $<4$; b) positif pour ceux classés APGAR $\geqq 8$; c) pour Apgar entre 5 et 7 les valeurs out été à la fois positives et négatives (Fig. '6).

$\mathrm{Si}$ on divise les décélérations tardives par rapport à la saturation d'oxygène de l'hémoglobine, on peut considérer que lorsque celle-ci est normale, le $\triangle \mathrm{BD}_{\mathrm{Hb}_{5}}$ materno-foetal est positif. Les valeurs négatives du $\triangle \mathrm{BD}_{\mathrm{Hb}_{5}}$ surviennent seulement en cas d'hypoxie foetale (Tab. VI).

\section{Conclusions}

Les résultats précisés ci-dessus semblent indiquer que:

1. le facteur métabolique de l'équilibre acidobasique foetal se réfléchit davantage dans le $\mathrm{BD}_{\mathrm{Hb}_{5}}$ que dans le pHqu 40 ou dans le BD non corrigé; 
2. dans le diagnostic d'acidose foetale maternogénique, le $\triangle B D_{\mathrm{Hb}_{5}}$ materno-foetal est un test plus sûr que le $\Delta \mathrm{pHqu} 40$, malgré l'étroite corrélation statistique entre les deux.

Si pendant le travail le $\mathrm{pH}$ foetal est bas et on reconnait que cette acidose foetale est d'origine maternelle, on peut décider de ne pas procéder à une extraction rapide du foetus; et la diminution du nombre des cas requérant une intervention augmentera propoptionnellement à la précision du paramètre utilisé pour la comparaison des facteurs métaboliques de l'équilibre acidobasique maternel et foetal.

Mots-clés: Acidose métabolique foetale maternogénique, analyse du sang foetale, bradycardie, déficit basique, équilibre acidobasique, pHqu 40, travail.

Acknowledgement: The authors are grateful to Miss Nella Castiglions for her valuable obstetrical and technical assistance.

\section{Bibliography}

[1] Aukland, K.: Spectrophotometric determination of hemoglobin oxygen saturation in small blood samples. Scand. J. Clin. Lab. Invest. 14 (1962) 533.

[2] BEARD, R. W.: Maternal-fetal acid-base relationships. In: ADAmsons, K.: Diagnosis and Treatment of fetal disorders. Springer, Berlin-Heidelberg-New York 1968

[3] Beard, R. W., G. M. Filshie, C. A. Knight, G. M. ROBERTS: The significance of the changes in the continuous fetal heart rate in the first stage of labour. J. Obstet. Gynaec. Brit. Cwlth. 78 (1971) 865

[4] BEARD, R. W., E. D. Morris: Foetal and maternal acidbase balance during normal labour. J. Obstet. Gynaec. Brit. Cwlth. 72 (1965) 496

[5] Beard, R. W., E. D. Morris, S. G. Clayton: pH of fetal capillary blood as an indicator of the condition of the foetus. J. Obstet. Gynaec. Brit. Cwlth. 74 (1967) 812

[6] Bowe, E. T., R. W. Beard, M. Finster, P. J. PopPERS, K. Adamsons, L. S. James: Reliability of fetal blood sampling. Maternal-fetal relationships. Amer. J. Obstet. Gynec. 107 (1970) 279

[7] Bretscher, J.: Kritische Bemerkungen zur transmaternalen Therapie fetaler Gefahrenzustände. In: Saling, E., J. W. Dudenhausen: Perinatale Medizin Band III. 4. Deutscher Kongreß für Perinatale Medizin, Berlin 1971. Thieme, Stuttgart 1972

[8] Bruns, P. D., R. N. Bernhardt, V. E. Drose, F. C. BAtTAGLIA: Effect of acute maternal metabolic acidosis on the rabbit fetus in utero and its relation to hyaline membrane disease in the newborn. Harper Hosp. Bull. 24 (1966) 127

[9] Caldeyro-Barcia, R.: Panel discussion „Aktuelle Fragen der neuzeitlichen Überwachung des Feten sub partu." In: Dudenhausen, J. W., E. Saling: Perinatale Medizin Band IV. 5. Deutscher Kongreß für Perinatale Medizin, Berlin 1972. Thieme, Stuttgart 1973.

[10] Dancis, J., M. Worth, P. B. Schneidau: Effect of electrolyte disturbances in the pregnant rabbit in the fetus. Amer. J. Physiol. 51 (1957) 551

[11] Derom, R.: De intrauteriene Hypoxie. Thesis Arscia Uitgaven, N. V. p. 84. Brussels 1964
[12] Goodin, R. C.: Intrapartum fetal heart rate responses and plethysmographic pulse. Amer. J. Obstet. Gynec. 110 (1971) 210

[13] Goodlin, R. C., I. H. KaIser: The effect of ammonium chloride induced maternal metabolic acidosis on the human fetus at term. I. pH, Haemoglobin, Blood Gases. Amer. J. Med. Sci. 233 (1957) 662

[14] Hrckr, E.-J.: Die Überwachung des Kindes unter der Geburt. (Methoden und Konsequenzen für die Geburtsleitung.) Geburtsh. u. Frauenheilk. 28 (1968) 298

[15] Hoebel, J. H.: Intrapartum clinical assessment of fetal distress. Amer. J. Obstet. Gynec. 110 (1971) 336

[16] Hon, E. H.: Instrumentation of Fetal Heart Rate and Fetal Electrocardiography. Obstetrics and Gynecology 30 (1967) 281

[17] Hon, E. H.: Instrumentation for Fetal Intensive Care. In: Saling, E., F.-J. Schulte, J. W. Dudenhausen: Perinatale Medizin Band II. 3. Deutscher Kongreß für Perinatale Medizin, Berlin 1970. Thieme, Stuttgart 1970.

[18] Hon, E. H., A. F. Krazin: Observations on fetal heart rate and fetal biochemistry. I. Base deficit. Amer. J. Obstet. Gynec. 105 (1969) 721

[19] Jacobson, L.: Studies on acid-base and electrolyte components of human foetal and maternal blood during labor. Studentlitteratur, Lund 1970

[20] James, L. S., E. T. Bowe, H. H. Balfour: Predictability and complications of fetal blood sampling. In: Adamsons, K.: Diagnosis and treatment of fetal disorders. Springer, Berlin-Heidelberg-New York 1968

[21] KUBLI, F.: Influence of labor on fetal acid-base balance. Clin. Obstet. Gynec. 11 (1968) 168

[22] Kubli, F., E. H. Hon, A. F. Khazin; H. Takemura: Observations on heart rate and $\mathrm{pH}$ in the human fetus during labor. Amer. J. Obstet. Gynec. 104 (1969) 1190

[23] Motoyama, E. K., G. Rivard, F. Acheson, C. D. Cook: The effect of changes in maternal $\mathrm{pH}$ and $\mathrm{pCO}_{2}$ on the $\mathrm{pO}_{2}$ of fetal lambs. Anesthesiology 28 (1967) 891

[24] Newman, W., P. Mrtchelr, C. Wood: Fetal acid-base status. Amer. J. Obstet. Gynec. 97 (1967) 52

[25] Rooth, G., L. JACOBSON: The value and validity of Base Excess ECF in Perinatal Acid-Base Studies. Scand. J. Clin. Lab. Invest. 28 (1971) 283 
[26] Rooth, G., R. McBride, B. J. Ivy: Fetal and maternal pH measurements. Acta Obstet. Gynec. Scand. 52 (1973) 47

[27] Roversi, G. D., V. Canussio: Relationship between fetal heart rate and acid-base balance during labor. In: Crosignani, P. G., G. Pardi : Fetal evaluation during pregnancy and labor. Academic Press, New YorkLondon 1971

[28] Roversi, G. D., V. Canussio: Die Bewertung der maternogenen Aziditätssteigerung beim Feten sub partu. In: Saling, E., J. W. Dudenhausen: Perinatalc Medizin Band III. 4. Deutscher Kongreß für Pcrinatale Medizin, Berlin 1971. Thieme, Stuttgart 1972

[29] Roversi, G. D., V. Canussro: L'acidosi fetale maternogenica in travaglio di parto. 1. Corso Nazionale di Aggiornamento in Medicina Perinatale, Milano 1972

[30] Saling, E.: Das Kind im Bereich der Geburtshilfe. Thieme, Stuttgart 1966

[31] Saling, E.: Fetal blood studies. In: Huntingford, P. J., K. A. Hürer, E. Saling: Perinatal Medicine, 1st European Congress of Perinatal Medicine, Berlin, 1968. Thieme, Stuttgart 1969

[32] Saling, E.: Panel discussion on "Clinical Surveillance of the fetus during labor". In: Crosignani, P. G., G. PArdr: Fetal Evaluation during Pregnancy and Labor. Academic Press, New York-London 1971

[33] Saling, E., J. W. Dudenhausen: The present situation of clinical monitoring of the fetus during labor. J. Perinat. Med. 1 (1973) 75
[34] Shenker, I..: Clinical experiences with fetal heart rate monitoring of one thousand patients in labor. Amer. J. Obstet. Gynec. 115 (1973) 1111

[35] Sigganid-Andersen, O.: The $\mathrm{pH} / \log \mathrm{pCO}_{2}$ blood acid-base nomogram revised. Scand. J. Clin. Lab. Invest. 14 (1962) 598

[36] SiggaArd-Andersen, O.: Blood acid-base alignment nomogram. Scand. J. Clin. Lab. Invest. 15 (1963) 211

[37] Siggand-Andersen, O.: Therapcutic aspects of acid-base disorders. In: Evans, F. T., T. C. Gray: Modern Trends in Anaesthesia. Butterworths, London 1967

[38] Sigganid-Andersen, O., K. Engel: A new acid-base nomogram and improved method for the calculation of the relevant blood acid-base data. Scand. J. Clin. Lab. Invest. 12 (1960) 177

[39] Siggaard-Andersen, O., K. Jorgensen, N. Naera: Spectrophotometric determination of oxygen saturation in capillary blood. Scand. J. Clin. Lab. Invest. 14 (1962) 298

[40] Sureau, C.: Recherches d'électro-cardiographie foetale au cours de la gestation ct du travail. Gynécologie et Obstétrique 55 (1956) 21

[41] Winters, R. W.: Studies of acid-base disturbances. Pediatrics 39 (1967) 700

[42] Wood, C., W. Newman, J. Lumley, J. Hammond: Classification of fetal heart rate in relation to fetal scalp blood measurements and Apgar score. Amer. J. Obstet. Gynec. 105 (1969) 942

Prof. Dr. G. D. Roversi

Institute of Obstetrics and Gynecology "L. Mangiagalli"

University of Milan, 1st. Department

Via della Commenda, 12

20122 Milano/Italy 